\title{
An Overview of the Therapeutic Effects of Camel Milk in the Treatment of Type 1 Diabetes Mellitus
}

\section{Abdalla KO*}

Department of Biochemistry, Faculty of Medicine and Health Sciences, University of Gadarif, Sudan

*Corresponding author: Abdalla KO, Department of Biochemistry, Faculty of Medicine and Health Sciences, University of Gadarif, Sudan, Tel: 249119246534; Fax: +249-4481-42578; E-mail: kamalabdalla7@yahoo.com

Rec date: March 10, 2014, Acc date: June 25, 2014, Pub date: June 29, 2014

Copyright: ( 2014 Abdalla KO. This is an open-access article distributed under the terms of the Creative Commons Attribution License, which permits unrestricted use, distribution, and reproduction in any medium, provided the original author and source are credited.

\begin{abstract}
The main treatment of type 1 diabetes mellitus (DM) is insulin replacement via parenteral routes, which is far from satisfactory. Camel milk is an alternative to current insulin treatment. This paper discusses the chemical constituents and properties of camel milk, recent experimental evidences about the effectiveness of camel milk in the treatment of insulin dependent diabetes mellitus, role of the camel milk in the restoration of damaged beta-cells of the pancreas and in the improvement of disturbed lipid metabolism associated with type $1 \mathrm{DM}$ as well as the effects of camel milk in the improvement of clinical function parameters of the kidneys and liver of subjects with insulin dependent diabetes mellitus.
\end{abstract}

This paper demonstrates that, camel milk causes significant reduction in insulin dosages in insulin dependent diabetic subjects to obtain glycemic control along with significant improvement in $\mathrm{HbA} 1 \mathrm{c}$ level, and improvement in micro albuminuria. Significant improvements were also observed in lipid metabolism, body mass index (BMI), biochemical parameters of the liver and kidney functions of camel milk fed experimental subjects with type-1 diabetes. Camel milk works as a regulator of blood sugar in the absence of original insulin, and it seems to work together with the body's own restorative and regenerative abilities. Camel milk is well tolerated and its uses are not associated with an increase in hypoglycemic events. Camel milk may be able to eliminate the alloxan and other chemicals' induced-toxicity on pancreas and on other body organs via regenerative effects on damaged cells and could be used as a restorative treatment of diabetes.

Keywords Camel milk; Type 1 diabetes mellitus; Treatment

\section{Introduction}

Diabetes mellitus is one of the most prevalent and serious chronic diseases to humans in nearly all countries. Study of the diabetes is important in order to allocate community and health resources and encourage measures to counteract trends for increasing prevalence. In 2011, the disease affected 366 million people worldwide, of which 4.6 million lost their lives [1]. The number is expected to have risen to 552 million by 2030 [1]. The prevalence of DM is particularly higher in low- and middle-income countries, which constitutes $80 \%$ of the people living with diabetes [1]. For instance in Sudan, a developing country in Africa, DM affects 2 million people; which is about $6 \%$ of its population, and the prevalence is about $20 \%$ in the capital Khartoum [2]. On the other hand, in 1999-2002, more than $9 \%$ of people 20 years of age and over and $25 \%$ of adults 60 years and over had diabetes in the USA, an indicator about the prevalence of DM in the developed world. In the USA the prevalence rates of DM was doubled between 1990 and 2005 [3,4]. Prevalence and mortality from DM in China and other Asian nations is high and is on the increase $[3,5]$. Diabetes mellitus is a group of metabolic disorders characterized by chronic hyperglycemia resulting from defects in insulin secretion, insulin action, or both. There are two major types of DM: type $1 \mathrm{DM}$ or insulin dependent DM (IDDM) and type $2 \mathrm{DM}$ or non-insulin dependent DM (NIDDM).

Type 1 diabetes mellitus is an organ specific autoimmune disease, characterized by loss of the insulin-producing beta cells of the islets of
Langerhans in the pancreas. This loss of beta cells leads to insulin deficiency. Type $1 \mathrm{DM}$ can be further classified as immune-mediated or idiopathic. The majority of type 1 diabetes is of the immunemediated nature, in which beta cell loss is a T-cell-mediated autoimmune attack. Before the advent of insulin, diabetes was treated with medicines derived from natural sources [5-10]. Recently, the search for appropriate anti-hyperglycemic agents has been focused on the types of food used in traditional medicine, because these medicines are natural products, not drugs [11]. The major treatment of type 1 $\mathrm{DM}$ is insulin replacement via parenteral routes, which is far from satisfactory. To overcome the drawbacks of parenteral insulin, scientists have developed oral insulin, hexyl-insulin monoconjugate-2 (HIM2), in which a single amphiphilic olignmer is covalently linked to the free amino group on the lys 29 residue of recombinant human insulin via an amide bond [12,13]. HIM2 alterations in physicochemical properties are a characteristic which resists the enzymatic degradation and facilitates absorption of the modified insulin. Oral insulin therapy presumably rated the best treatment, but it has several drawbacks. It takes more time and efforts, it is expensive, and its coagulum formation nature in the stomach due to acidic environment reduces its effectiveness and is accompanied with constant episodes of abnormally hypoglycemia and gain in weight [14]. These force people to adopt alternative therapies [14]. Chronic hyperglycemia causes long-term damage, dysfunction, and failure of various organs of the body. The most suffered organs are the eyes, kidneys, nerves, heart and blood vessels [15]. Furthermore, untreated diabetes causes a number of serious acute and long-term complications. Acute complications include hyperglycemia, diabetic ketoacidosis, or non-ketotic 
hyperosmolar coma. Serious long-term complications include cardiovascular disease, chronic renal failure, and diabetic retinopathy, the latter is notably responsible for $8 \%$ of blindness in the US [16].

DM is the leading cause of new cases of blindness in the world. Each year 12,000 to 24,000 people lose their sight because of DM and is the leading cause of new cases of blindness in adults at the age of 20-74 years old [16]. In addition, 78,000 children develop type 1 diabetes every year and it interrupts normal child development and carries the threat of severe complications in the active period of their lives [17] There is no known preventive measure against type 1 diabetes, which causes approximately $10 \%$ of DM cases in North America and Europe. Most affected people are otherwise healthy and of a healthy weight when onset occurs. Type 1 diabetes can affect children or adults, but was traditionally termed "juvenile diabetes" because majorities of these diabetes cases were in children. Diabetes mellitus interrupts normal child development and carries the threat of severe complications in the active period of their lives. It is therefore, urgently needed to search for safe and more effective therapies for DM, either as complementary or alternative to existing treatment programs as no drug has been shown to modify the course of diabetic complications $[13,18]$.An alternative to current insulin treatment of DM is Camelusdromedarius milk [18-28]. Moreover, Camelusdromedarius milk has shown to have exceptional broad therapeutic qualities on other serious human diseases [24,29-32].

In the coming pages, I discus the chemical constituents and properties of camel milk, recent experimental evidences about the effectiveness of camel milk in the treatment of insulin dependent diabetes mellitus, role of camel milk in the restoration of damaged beta-cells of the pancreas and in the improvement of disturbed lipid metabolism associated with type 1 diabetes mellitus as well as the effects of camel milk in the improvement of clinical function parameters of the kidneys and liver of subjects with insulin dependent diabetes mellitus.

\section{Chemical Constituents and Properties of Camel Milk}

Dromedary milk is pure white as the fats are finely homogenized throughout the milk. Camel's milk chemical composition is different from that of other mammals. Camel milk has high percentage of water content, which ranges from $86-91 \%$ [19], and it is inversely proportioned to the availability of drinking water to camels. This makes camel milk a valuable source of water for suckling young camels and the camel herdsmen who are normally live in scarce water areas. Fresh camel milk has a $\mathrm{pH}$ of $6.4 \pm 0.18$ [18]. This $\mathrm{pH}$ of the milk allows enhanced absorption of milk constituents from the duodenum, especially the iron. When camel milk is left to stand, the acidity rapidly increases [24]. The lactic acid content increases from 0.03 percent after standing 2 hours to 0.14 percent after 6 hours [24]. The first camel milk after delivery, the colostrums, is white and slightly diluted as compared with the colostrums of cow. Its 3 hours post-partum total solids averaged $30.4 \%$ [33], and it declines to $18.4 \%$ during the first 2 days of lactation. This decline in T.S. is then greatly decreased to $5.8 \%$ and is rather caused by a decline in total proteins and minerals [33]. Camel milk contains high concentration of insulin i.e. 52 U/L [20] to $59 \mathrm{U} / \mathrm{L}$ [34]. The milk also contains one protein that possesses many characteristics similar to human insulin [21]. Camel milk is not affected by acidic environment and does not form coagulum in acidic environment such of the stomach [22]. This lack of coagulum formation allows the camel milk to pass rapidly through stomach together with the specific like protein/insulin and remains available for absorption in intestine. It was proposed that, this unique property of camel milk gives it the advantage to serve as a vehicle and a protector that facilitates the absorption of intact molecules of insulin by the small intestine [14]. Camel milk contains little fat, in average about $2 \%$; and this fat consists mainly of polyunsaturated fatty acids that are completely homogenized and gives the milk its smooth white appearance [24]. Camel milk has high concentrations of volatile acids especially the essential fatty acid, linoleic acid and other polyunsaturated fatty acids, which are essential for human nutrition [30]. Fats in camel milk dispersed as small micelles instead of a layer that are non-reactive to acid [35]. Camel milk is low in cholesterol 40folds lesser than cholesterol concentration in caw milk [24]. Camel milk has high content of ascorbic acid of $5.7-9.8 \%$, which is 3 times greater than of other mammalian milks [36]. Camel milk is also rich in other vitamins such as B12, E, B1, B2 and A. Camel milk has high concentrations of minerals such as calcium, iron, magnesium, cupper, manganese, sodium, phosphorus, zinc and potassium [24]. Lactose in camel milk, presents in average concentrations of $4.8 \%$, but this milk sugar is easily metabolized by persons suffering from lactose intolerance [24]. The proteins of camel milk do not cause food allergies, because camel milk contains no beta-lactoglobulin [37] and a different beta-casein [38], the two proteins in cow milk that are responsible for allergies. Immunoglobulins $\operatorname{IgM}, \operatorname{IgG}, \operatorname{Ig} A$ and $\operatorname{IgD}$ have been detected in camel sera on the basis of cross-reactivity with human immunoglobulins [39]. Camel immune system is different from all other mammalians [40]. Camel milk immunoglobulin subclasses IgG2 and IgG3, which are natural for camels, consist of only two heavy chains. Light chains (VL) are not present. These are naturally occurring antibodies devoid of light chains. There is a single $\mathrm{V}$ domain (VHH) [41]. Camel milk IgG2 and IgG3 VHH have a long complementary determining region (CDR3) loop, compensating for absence of the VL [42]. The conventional immunoglobulins are large long and short-chained domains, having difficulties reaching and penetrating antigens [43]. As camel immunoglobulins have no short chains and small so are active against antigens. The camel's immunoglobulins pass into the milk and so are available for combating autoimmune diseases. The most pertinent factor is that conventional treatments of autoimmune diseases are based on immune-suppression, while camel milk immunoglobulins enhance the immune system, thus revitalizing immune integrity [31,33]. Viral enzymes play a key role in triggering diseases, and by neutralizing them a replication of viruses would stop. A camel variable domain antibody fraction is a potent and selective inhibitor of the HepatitisC enzyme system [4]. This explains the extreme resistance to many deadly animal viral diseases like Foot \& Mouth, Rift Valley fever and Rinderpest [39]. Conventional antibodies rarely show a complete neutralizing activity against enzyme antigens. Camel milk IgG has a full neutralizing activity against tetanus toxin as it enters the enzymes structure. Camel hypervariable regions have increased repertoire of antigen binding sites [42]. Camel milk IgG2 and IgG3 VHH domains are better suited to enzyme inhibitors than human antibody fragments [41], thus offering a potential for viral enzymatic neutralization [44]. Camel milk contains various other protective proteins, mainly enzymes which exert antibacterial and immunological properties [45]. The protective proteins in camel milk, include, $\mathrm{N}$-acetylglucosaminidase (NAGase), the milk enzyme, NAGase is an accepted test for mastitis in cows. When it was first documented that camel milk was rich in NAGase it was assumed that those camels suffered from subclinical mastitis. However after checking camel and llamas milk [46] all with high NAGase levels, it was concluded that NAGase has an antibacterial activity and so strengthens the antibacterial- 
antiviral activity of the milk. It is noteworthy that the NAGase activity is similar to that in women's milk, confirming the nutritional advantages of camel milk over cow milk. Camel milk contains lysozymes, which participate in primary immune system. Lactoferrin, which are iron-saturated lactoferrin and prevents microbial growth in gut, participates in primary immune system. Camelid milk apparently contains much more lactoferrin than in ruminant milk [46]. Lactoperoxidase in camel milk contributes to the non-immune host defense system and exerting bactericidal activity, mainly on gramnegative bacteria it has growth promotion activity and anti-tumor activity [47], and is analogue of $71 \%$ to human thyroid peroxidase, which is involved in iodination and coupling in the formation of the thyroid hormones. Camel milk has the highest concentrations of peptidoglycan recognition protein (PGRP) among milks of other mammals. This protein was discovered in camel milk and it has apparent effect on breast cancer [48] by controlling metastasis [49]. It stimulates the host's immune response. It has a broad antimicrobial activity.

\section{Experimental Evidences of Therapeutic Effects of Camel Milk on IDDM}

Patients with type 1 diabetes suffer chronic hyperglycemia and dysfunction of carbohydrates, fat and protein metabolism [50,51]. Effect of camel milk in comparison to cow's milk on blood glucose, triglycerides, alanine-amino transferase (ALT) and asparate-amino transferase (AST) levels in healthy female albino rats was studied [52]. At the end of the study period, rat blood samples were analyzed. No significant difference in glucose, triglyceride, AST and ALT activity was detected between the control and treated groups. But cholesterol levels of both $100 \%$ cow and $100 \%$ camel milk treated rats were shown to be significantly lesser than control group. It can be concluded from this study that camel milk can be safely consumed by non-diabetics or healthy individuals.

Study to analyze the anti-diabetic effects of camel milk in streptozotocin-induced diabetic rats by assaying liver and kidney clinical function parameters was conducted [53]. Administration of streptozotocin to the experimental groups of rats resulted in marked detectable changes. The rats were fed daily with fresh camel milk for 30 days. The effects of camel milk on blood glucose, serum proteins, blood urea, uric acid, creatinine, lipid profile and the activities of diagnostic marker enzymes of liver and alkaline phosphatase (ALP) in the plasma/serum of control and experimental groups of rats were evaluated. The results of this study showed that, camel milk feeding to diabetic rats significantly reduces the levels of blood glucose, urea, uric acid and creatinine and increases the activities of albumin, albumin/ globulin ratio and restores all liver function marker enzymes and lipid profile to near control levels. The data of this study demonstrated that camel milk has anti-hyperglycemic effects and alleviate liver and renal damage associated with streptozotocin-induced diabetic mellitus.

The hypoglycemic effect of camel milk in comparison to cow and buffalo milks in stretozotocin-induced diabetic rats was carried out [34]. The effects of camel, cow and buffalo milks on liver and kidney functions of the diabetic rats in comparison to a control group and groups fed with cow and buffalo milks were also investigated. The study revealed that, camel milk was most effective in hypoglycemic control of the diabetic rats; it reduced hyperglycemia by $49.2 \%$, while cow and buffalo milks reduced hyperglycemia by $11.6 \%$ and $11.1 \%$ respectively. Also, camel milk improved liver enzyme functions of alanine-amino transferase and aspartate amino transferase by 41 and
$38 \%$ respectively compared to cow and buffalo milk fed diabetic group. Also, camel milk showed significant normalization effects in blood uric acid, urea, and creatinine of the diabetic study group. The findings of this study demonstrated that, camel milk has marked glycemic control and positive effects on liver and renal functions of diabetic subjects. Effect of oral insulin carried by camel milk on type 1 diabetes patients in comparison with both insulin injection requirements and camel milk alone was studied [14]. Fifty randomly selected type 1 diabetic patients were divided into three groups; A, B and C. Group B in addition to usual care received $0.5 \mathrm{~L}$ of camel milk daily, while group $\mathrm{C}$ in addition to usual care received insulin mixed with $0.5 \mathrm{~L} \mathrm{ml}$ of camel milk daily. Results of this study showed significant improvements in fasting blood sugar, post parandial blood sugar, $\mathrm{HbAlc}$ and significant reduction in insulin requirement in group $\mathrm{C}$ receiving insulin mixed with camel's milk in comparison with groups A and B. This study proved that camel milk mixed with insulin was effective supplementation, as adjunctive therapy in management of type 1 diabetes.

Efficacy of camel milk on alloxan-induced diabetic dogs was investigated [18]. Alloxan injection caused a toxic effect on kidney and liver in addition to the pancreas. Two diabetic dog groups: group 1, received $0.5 \mathrm{~L}$ raw camel milk. Group 2 received $0.5 \mathrm{~L}$ raw cow milk, an additional third healthy group of dogs was used as control; these dogs received $0.5 \mathrm{~L}$ raw camel milk. By the end of the study, group1 showed a significant decline in blood glucose, cholesterol and total proteins. In the contrary, group 2 showed hyperglycemia, increase in cholesterol, and increase in total proteins. The diabetic state of group 2 was confirmed by glucose tolerance test. After then, the dogs of group 2 were treated, in test 2 , with $0.5 \mathrm{~L}$ camel milk for 5 weeks instead of caw milk. At week 4, blood glucose level for these dogs showed a significant decrease, a similar improvement was occurred in total proteins and in cholesterol. Dogs from group 1, which were used to follow the effect of camel milk by the end of experiment, showed healthy state: normal blood glucose levels, normal cholesterol, normal triglycerides and normal total proteins. The stability of the glycemic state of dogs received camel milk was confirmed by glucose tolerance test (GTT). The steadiness of this glycemic state was observed since week 3 and after stopping of camel milk. The results of this study clearly demonstrated that, camel milk has a therapeutic effect on alloxan-induced diabetic dogs and restoration of the pancreatic function.

Therapeutic effects of camel milk on streptozotocin-induced diabetic male albino rats were studied [54]. The levels of total cholesterol (TC), triglycerides (TGs) free fatty acids (FFAs), phospholipids (PLs), high density lipoprotein-cholesterol (HDL-C), low density lipoprotein-cholesterol (LDL-C) and very low density lipoprotein-cholesterol (VLDL-C) were assayed in the plasma and tissues of the liver, kidneys and heart of a control (received no camel milk) and a studied group (received camel milk). By the end of the study they observed significant increase in total cholesterol, triglyceride, free fatty acids, LDL-C and VLDL-C in plasma and tissues of the streptozotocin-induced diabetic male albino rats, while plasma HDL-cholesterol was significantly decreased in the group. Treatment of these rats with camel milk helped to cure the above changes till normalcy. Thus, this study demonstrated that, camel milk was good in reducing hyperglycemia and hyperlipidemia associated with diabetes mellitus.

A study to investigate the effects of camel milk in comparison with insulin in the treatment of experimentally-induced diabetes was 
carried out by [55] on New Zealand rabbits. The rabbits were divided into 4 groups by 10 rabbits each. Group1 was control, non-diabetic and received normal saline only. The other 30 rabbits were injected intravenously with alloxan for induction of diabetes mellitus and then divided into 3 groups, ten rabbits in each as following: group 2 considered as control diabetic and left untreated, group 3 was considered as diabetic and treated with insulin, and group 4 was considered as diabetic and received camel milk. At the end of the study, blood and tissue samples (liver, kidney and pancreas) were collected from all the rabbits for analysis of enzymatic superoxide dismutase (SOD) activity and catalase, non-enzymatic glutathione (GSH) antioxidant enzyme activities. Serum malondialdeyde, glucose, insulin and lipid profile were also analyzed. The results of the study showed that, camel milk was effective in the treatment of the induced diabetes in comparison to insulin treatment alone. In addition to that, camel milk helped to improve the diabetes-induced oxidative stress. The histopathological examination of tissues of these animals revealed that, there was regeneration of $\beta$ cells and the islets of Langerhans among the pancreatic acini in rabbits receiving camel milk. These findings suggested that the camel milk administration in case of insulin dependent diabetes mellitus might be recommended as an oral anti-diabetic remedy for this chronic disease.

A randomized study to evaluate the efficacy of camel milk as an adjuvant therapy in young type 1 diabetic patients was achieved by [56]. They enrolled 54 type 1 diabetic patients with an average age of 20 years. Subjects were randomly divided into two groups of 27 patients. Group 1 received usual management, whereas group 2 received $500 \mathrm{ml}$ of camel milk daily in addition to standard management as for group 1. A third group, annotated as a control group of 10 healthy subjects was also assessed. After the study period, significant differences were observed between the usual-management groups versus the camel milk received group: fasting blood sugar, HbA1c, serum anti-insulin antibodies, urinary albumin excretion, daily insulin dose and body mass index. C-peptide levels were markedly higher in the camel milk received group. The results of this study has shown that, $500 \mathrm{ml}$ daily consumption of camel milk by type 1 diabetic patients as an adjunct to standard management of DM; can better manage DM and improve metabolic control.

The efficacy of camel milk as an adjunct to routine diabetic management in maintaining long-term glycaemia control in type I was assessed by [57]. Throughout the study, 12 randomly assigned patients underwent routine diabetic management and 12 randomly assigned patients additionally undertook daily consumption of raw camel milk (500ml/day). Glycosylated haemoglobin (HbAlc) and BMI were measured at the initiation of the study and monitored at 3 monthly intervals. Additionally, plasma insulin, C-peptide and anti-insulin antibodies were measured at the beginning and end of the study. In the group receiving camel milk, there was a significant increase in MBI and a significant reduction in HbAlc, mean blood glucose and necessary insulin dose compared to the values at the initiation of the study. In addition to that, one patient of the group is completely cured from DM after 8 months of consumption of camel milk, and gets rid of using insulin totally. In the contrary, there was no significant change in c-peptide or anti- insulin antibodies. This study demonstrated that, camel milk, as an adjunct to insulin therapy, was safe and efficacious in improving long-term glycaemic control, and helps in the reduction of insulin requirement in type 1 diabetic patients. Camel milk was well tolerated and its use was not associated with an increase in hypoglycemic events.
The effects of raw camel milk on male albino rats that were rendered diabetic by a single intra peritoneal injection of streptozotocin were studied [28]. Streptozotocin induced diabetic rats were randomized to receive raw camel milk, pasteurized camel milk, raw camel milk+lactoferrin, or cattle milk and control [non diabetic rats $(n=8)]$ which were followed for 4 weeks. There was significant difference with raw camel milk, this difference is decreased after pasteurization and there was no added advantage after adding lactoferrin. The present study indicates that there was significant decrease in mean blood sugar level in diabetic rats getting raw camel milk. There were no added advantages of adding lactoferrin in raw camel milk. Hypoglycemic activity of camel milk decreases after pasteurization. This study showed that, raw camel milk may be a therapeutic adjunctive option for diabetes mellitus in humans.

Efficacy of camel milk on glycemic control, risk factors and diabetes quality of life in patients of type 1 diabetes was studied by [58]. Twenty four randomly selected patients with type 1 diabetes were enrolled in this study. They divided the patients into two groups. Group 1 (12 patients) received usual care and group 2 (also 12 patients) received $500 \mathrm{ml}$ camel milk in addition to usual care. Baseline data of both the groups were similar in demographic and variables. After 3 months of treatment there were significant improvements in fasting blood sugar and $\mathrm{HbA1c}$ levels and significant reduction in insulin requirement in patients receiving camel milk. Diabetes quality of life score improved significantly in the form of change in satisfaction. There was $30 \%$ reduction in doses of insulin in $92 \%$ of patients of group 2 . However, there were no statistically significant changes in lipid profile, plasma insulin and c-peptide. This study showed that, camel milk proved effective supplementation in the management of type 1 diabetes.

\section{Discussion and Conclusion}

Besides drugs (insulin, sulphonylureas and biguanides), classically used for the treatment of diabetes, consumption of camel milk is a common practice in Africa, Asia and the Middle East for the treatment of diabetes mellitus. Camel milk is well known, in arid and semi-arid regions, for its medicinal properties [24].

Camel milk contains high concentration of insulin; this may be the reason for lesser requirement of insulin in camel milk feeding groups with diabetic mellitus. Oral insulin has been known since many years but its drawbacks such as its coagulum formation in acidic environment in stomach thereby neutralizing its potency [24]. The lack of coagulum formation in acidic media of camel milk may act as an effective vehicle to take the insulin present in it unchanged to the intestine and from there it can be absorbed. Moreover, amino acid sequence of some of the camel milk proteins is rich in half cystine has superficial similarity with insulin family of peptides were reported [21].

Electrophoresis of camel milk's and shubat's proteins and their microelement compositions were determined [59]. Electrophoresis revealed two bands in camel's milk and several in shubat. Camel milk was shown to be low in fat and contains no cholesterol. It contains lower lactose, higher levels of potassium, iron and vitamin $\mathrm{C}$, and large concentrations of insulin [20,59].

Diabetes mellitus is defined as a state of chronic hyperglycemia associate with dysfunction of carbohydrate metabolism. Dysfunction of carbohydrate metabolism, eventually leads to dysfunction of lipid, carbohydrate and nucleic acid metabolism [24]. 
The metabolic disorders of diabetes mellitus can be induced experimentally by injection of alloxan or streptozotocin to experimental animals. Alloxan induced-diabetes is caused by the selective pancreatic beta cell toxicity $[60,61]$. In order to destroy insulin- producing cells and to induce a state of insulin-dependent diabetes mellitus, alloxan is structurally analogue to glucose, and is taken up into the cell via the low affinity GLUT 2 glucose transporters in the plasma membrane [62]. Several species such as rats, rabbit and dogs are sensitive to alloxan toxicity [63]. Alloxan-induced diabetes causes minimal beta cell activity, hyperglycemia, hypercholesterolemia and hyperproteinaemia [18]. Alloxan injection causes damage to kidneys, liver and the pancreas [64].

The toxicity of alloxan to kidneys may be attributed to its toxic effects on the proximal convoluted renal tube [65]. Camel milk causes significant decrease in blood glucose on alloxan-induced diabetic dogs [18]. The hypoglycemic effect of camel milk appeared since week 3 of giving the milk to experimental animals and continuous up to normal levels of blood glucose [18]. The stability of the glycemic state was confirmed by GTT. This stability was associated with decline in cholesterol concentrations and this steadiness last after ceasing camel milk [18].

Since blood glucose, proteins and lipids profiles were controlled by endocrine, paracrine and autocrine interactions; there might be more active principles in camel milk (peptides, vitamins, fatty acids and etc.) [66]. High mineral contents of camel milk such as iron, sodium, potassium, copper and magnesium and high level of vitamin $\mathrm{C}$ may act as antioxidants that scavenge free radicals from the cells, this might provide additional benefit to camel milk $[67,68]$. Camel milk could eliminate the alloxan and other chemical toxicities on pancreas, liver and kidney via regenerative effects on damaged cells and could be used as a restorative treatment of diabetes [24].

Hypoglycemic effect of camel milk is slower when the diabetic animals were previously treated with cow milk. This might due to the fact that, cow milk proteins might serve as a trigger for the development of diabetes in susceptible subjects. In this context, elevated levels of anti-bovine serum albumin antibodies were detected in diabetic animals and patients $[68,69]$. The efficacy of camel milk in the treatment of allaxan-induced diabetes mellitus may have an important implication for the management of diabetes mellitus in humans. But further studies are warranted to elucidate the exact mechanisms of action of camel milk.

There are strong evidences that oral insulin products would provide insulin in a more effective physiological manner, resulting in a decrease in peripheral insulin concentrations this "insulinsing" the live $[70,71]$.

Consumption of milk for the treatment of DM is itself a point of contention as insulin, being a protein, is normally destroyed in the stomach [72]. Intestinal absorption of large proteins and, therefore, insulin is only possible in the first few days of life [73].

Camel milk contains high amounts of ascorbic acid [36], it does not react to the acid and not form coagulum in acidic environment [22]. These properties might allow camel milk to pass readily the intestines for absorption with its intact insulin molecules. Lack of coagulum formation of camel milk in acidic media and its antibacterial and antiviral activities might lie behind the efficacy of camel milk in the treatment of IDDM. The decline in blood glucose followed camel milk consumption validates the fact that camel milk acts on regulating cellular sugar in the absence of endogenous insulin and in presence of exogenous oral insulin.

Removal of free radicals by camel milk prevents tissues damage including the $\beta$-cells of the pancreas [74]. Free radicals play a role in the enhancement of oxidation of LDLs and the exhaustion of HDLs. The two opposing processes are atherogenic. The high concentrations of antioxidants in camel milk and the effects of camel's milk in lowering body fats in healthy individuals and in patients with IDDM might hone the insulin receptors to become more responsive to available insulin in camel milk.

Healthy individuals with low BMI and diabetic patients consumed camel milk, showed significant improvement in mean BMI [24]. The positive effect in weight gain and corrections of lipid profile in individuals consuming camel milk might attributed to camel milk high nutritional value, relative lower fat percent and extremely low cholesterol. Camel milk is very nutritious, tonic and has a high satiety value. It possesses hypoallergenic, antibacterial, antiviral, hypoglycemic and other medicinal properties and fully compatible with human milk [24].

Camel milk is the most beneficial for human nutrition [75]. Nutrition plays a vital role in health maintenance and in the prevention of diseases. There was marked improvement in diabetes quality of life score of camel milk treatment; this could be a result of an improved glycemic control or anabolic effect of camel milk with good amount of lysozyme, lactoferrin, lactoperoxidase, immunoglobulin Gs and secretary immunoglobulin A in camel milk.

Interestingly, fats of camel's milk disperse in small micelles in instead of a large layer, this in contrast of milk of other mammals. Moreover, camel milk is non-reactive to acid and the churning effect of the stomach and the quality and quantity of these fats are largely different from those of other mammals. The existence of fats in the form of small micelles might allow one to postulate that, these fat micelles might form particles or a kind of conjugates with insulin and insulin-like molecules of camel milk with persistent qualities to pepsin digestion and facilitate insulin's absorption as intact molecules through the small intestine. Strong buffering capacity of camel milk and insulin-analogue peptides of camel milk with rich cystine repeats are also interesting and warrant further studies.

In conclusion, camel milk causes significant reduction in insulin doses in insulin dependent diabetic subjects to obtain glycemic control along with significant improvement in $\mathrm{HbAlc}$ level, and improvement in micro albuminuria. Significant improvements were also observed in lipid metabolism, BMI, biochemical parameters of the liver and kidney functions of camel milk fed experimental subjects with type-1 diabetes. Camel milk works as a regulator of blood sugar in the absence of original insulin, and it seems to work together with the body's own restorative and regenerative abilities. Camel milk is well tolerated and its uses are not associated with an increase in hypoglycemic events, and it may be able to eliminate the alloxan and other chemicals' induced-toxicity on pancreas and on other body organs via regenerative effects on damaged cells and could be used as a restorative treatment of diabetes.

\section{References}

1. Wild S, Roglic G, Green A, Sicree R, King H (2004) Global prevalence of diabetes: estimates for the year 2000 and projections for 2030. Diabetes Care 27: 1047-1053. 
2. Sudan Federal Ministry of Health (2012). Press release. Alsahafa newspaper 09 November.

3. Sachdev B (2012) Screening of type 2 diabetes mellitus and its associated risk factors among select tribes of Rajasthan. IJHSR 1:33-44.

4. Diabetes and retinopathy (Eye Complications) (2007). American Diabetes Association http://www.diabetes.org/diabetes-statistics/eyecomplications.jsp.

5. Li R, Wang ZG (2003) Analysis and forecast of the mortality of diabetes mellitus in China. J Environ Occupational Mod. 20:168-171.

6. Lee SH, Chun HK, Lee YS (2003) The effect of rice germ oil supplement on serum and hepatic lipid levels of streptozotocin-induced diabetic mice. Korean Journal of Nutrition 36:543-548.

7. Fujita H, Yamagami T, Ohshima K (2003) Long-term ingestion of Touchi extract, an a-glucosidase inhibitor, by borderline and mild type- 2 diabetic subjects is safe and significantly reduces blood glucose levels. Nutrition Research 23:713-722.

8. Lee SH, Chun HK, Park HJ, Chang SO, Lee YS (2004) Effects of coryzanol on blood glucose in diabetic KK mice. J KorSoc Food SciNutr 33:827- 831.

9. Lee SH, Park HJ, Cho SY, Han GJ, Chun HK et al. (2004) Supplementary effect of the high dietary fiber rice on lipid metabolism in diabetic KK mice. Korean J Nutr 37:81-87.

10. Arnold Bloom (1980) WHO Expert Committee on Diabetes Mellitus: second report. J R Soc Med 73: 834.

11. Hu X, Sato J, Oshida Y, Xu M, Bajotto G, et al. (2003) Effect of Goshajinki-gan (Chinese herbal medicine: Niu-Che-Sen-Qi-Wan) on insulin resistance in streptozotocin-induced diabetic rats. Diabetes Res ClinPract 59: 103-111.

12. Gordon Still J (2002) Development of oral insulin: progress and current status. Diabetes Metab Res Rev 18 Suppl 1: S29-37.

13. Chaillous L, Carel JC, Thivolet C et al. (1999) Lack of effect of one year oral insulin therapy in recent-onset type 1 diabetes: Results of a multicentric randomized controlled trial. Diabetologia; 42: A62- A62.

14. Kotb-El-Sayed M, Al-Shoeibi ZY, Ahmed A, Zayed AA (2011) Effects of camel's milk as a vehicle for insulin on glycemic control and lipid profile in type 1 diabetes. American Journal of Biochemistry and Biotechnology 7: 179-189.

15. American Diabetes Association (2008) Diagnosis and classification of diabetes mellitus. Diabetes Care 31 Suppl 1: S55-60.

16. Liu S1, Zhang Y, Xie X, Hu W, Cai R, et al. (2007) Application of twodimensional electrophoresis in the research of retinal proteins of diabetic rat. Cell MolImmunol 4: 65-70.

17. Dahlquist GG (1999) Primary and secondary prevention strategies of pre-type 1 diabetes. Potentials and pitfalls. Diabetes Care 22 Suppl 2: B4-6.

18. Sboui A, Djegham M, Khorchani T, Hammadi M, Barhoumi $\mathrm{K}$ et al. (2010) Effect of camel milk on blood glucose, cholesterol and total proteins variations in alloxan-induced diabetic dogs. Int'l J. of diabetes and metabolism 18:5-11.

19. Yagil R, Zagorski O, Creveld CV, Saran A (1994) Science and Camel Milk Production. In: Chameaux et Dromedaires, AnimeauxLaitiers, G. SaintMartin, (Edn.); Expansion ScientifiqueFrancaise, Paris, 75-89.

20. Singh R (2001) Annual Report of National Research Center on Camel. 1st Edn. Bikaner, India,pp: 50.

21. Beg OU, von Bahr-Lindström H, Zaidi ZH, Jörnvall H (1986) Characterization of a camel milk protein rich in proline identifies a new beta-casein fragment. RegulPept 15: 55-61.

22. Wangoh J (1993) what steps towards camel milk technology? Int. J. Anim. Sci 8:9-11.

23. Shehadeh N, Gelertner L, Blazer S, Perlman R, Solovachik L, et al. (2001) Importance of insulin content in infant diet: suggestion for a new infant formula. ActaPaediatr 90: 93-95.

24. Kamal O Abdalla (2012) Treatment of Incurable Ailments with Camel's Milk and Urine, based on Scientific Research, book in Arabic (ElaajAlamraadAlmostasia Be-labanWa-bool Al-ebeel, Be-esbaat Al- bahth Al-elmi). ISBN: 978-99942-64-15-5. Int'l University of Africa Press. Sudan.

25. Davis SN, Dobbins R, Colburn C, Tarumi C, Jacobs J, et al. (1993) Effects of hyperinsulinemia on the subsequent hormonal response to hypoglycemia in conscious dogs. Am J Physiol 264: E748-755.

26. Wan CK, Giacca A, Matsuhisa M, El-Bahrani B, Lam L, et al. (2000) Increased responses of glucagon and glucose production to hypoglycemia with intraperitoneal versus subcutaneous insulin treatment. Metabolism 49: 984-989.

27. Pozzilli P, Pitocco D, Visalli N, Cavallo MG, Buzzetti R, et al. (2000) No effect of oral insulin on residual beta-cell function in recent-onset type I diabetes (the IMDIAB VII). IMDIAB Group. Diabetologia 43: 1000-1004.

28. Agrawal RP, Sahani MS, Tuteja FC, Ghouri, SK, Sena DS, et al. (2005) Hypoglycemic activity of camel milk in chemically pancreatectomized rats- An experimental study. Int J DiabDev Countries 25: 75-79.

29. Yagil R, Saran A, Etzion Z (1984) Camels' milk: for drinking only? Comp BiochemPhysiol A Comp Physiol 78: 263-266.

30. Agrawal RP, Kochar DK, Sahani MS, Tuteja FC, Ghorui SK (2004) Hypoglycemic activity of camel milk in streptozotocin induced diabetic rats. Int. J. DiabDev Countries 24:47-49.

31. Yagil R (1987) Camel Milk. A Review. Int. J. Anim. Sci. 2: 81-89.

32. el Agamy EI, Ruppanner R, Ismail A, Champagne CP, Assaf R (1992) Antibacterial and antiviral activity of camel milk protective proteins. $J$ Dairy Res 59:169-175.

33. Yagil R, van Creveld C (2000) Medicinal use of camel milk. Fact or Fancy? In :Proc. 2nd Intl.CamelidConf.Agro-economics of Camelid Farming. Almaty September P80.

34. Hamad EM, Abdel-Rahim EA, Romeih EA (2011) Beneficial effect of camel milk on liver and kidneys function in diabetic Sprague-Dawley rats. Int. J. of Diary Science 6: 190-197.

35. Abu-Lehia (1989) Medical and Chemical Characteristics of Camel Milk fat and its fractions. Food chem.; 34: 261-268

36. Farah Z, Rettenmaier R, Atkins D (1992) Vitamin content of camel milk. Int J VitamNutr Res 62: 30-33.

37. Merin U, Bernstein SD, Block-Damti N, Yagil R, van Creveld C, et al. (2001) A comparative study of milk serum proteins in camel (camelusdromedarius) and bovine colostrum. Livestock product Science 67: 297-301.

38. Beg OU, Strom VBLH, Zaidi ZH, Jornvall H (1986) A camel milk protein rich in half cystine. Primary structure assessment of variations, internal repeat patterns and relationship with neurophysin and other active polypeptides. Eur J Biochem 5: 195-201.

39. Hamers R (1998) Immunology of camels and llamas. In: Handbook of Veterinary 111 Immunology. Eds: PP. Pastoret, P. Griebel.\& A. Gaevarts. Academic Press, UK; 437-421.

40. Hamers-Casterman C, Atarhouch T, Muyldermans S, Robinson G, Hamers C, et al. (1993) Naturally occurring antibodies devoid of light chains. Nature 363: 446-448.

41. Riechmann L, Muyldermans S (1999) Single domain antibodies: comparison of camel VH and camelised human VH domains. J Immunol Methods 231: 25-38.

42. Muyldermans S, Cambillau C, Wyns L (2001) Recognition of antigens by single-domain antibody fragments: the superfluous luxury of paired domains. Trends BiochemSci 26: 230-235.

43. Martin F, Volpari C, Steinkuhler C, Dimasi N, Brunetti M, et al. (1997) Affinity selection of a camelized $\mathrm{V}(\mathrm{H})$ domain antibody inhibitor of hepatitis C virus NS3 protease. Protein Eng 10: 607-614.

44. El-Agamy EI (2000) Specific immunoglobulins to human rota virus in camel colostrum and milk. In: Proc. 2nd Intl.Camelid Conf. Agroeconomics of Camelid Farming. Almaty P98.

45. Kappeler S (1998) Composition and structural analysis of camel milk proteins with emphasis on protective proteins. PhD thesis ETH No. 12947, Zurich. 
46. Morin DE, Rowan LL, Hurley WL (1995) Comparative study of proteins, peroxidase activity and $\mathrm{N}$-acetyl- $\$$-glucosaminidase activity in llama milk. Small Ruminant Research 17: 255-261.

47. Ueda T, Sakamaki K, Kuroki T, Yano I, Nagata S (1997) Molecular cloning and characterization of the chromosomal gene for human lactoperoxidase. Eur J Biochem 243: 32-41.

48. Kiselev SL, Kustikova OS, Korobko EV, Prokhortchouk EB, Kabishev AA, et al. (1998) Molecular cloning and characterization of the mouse tag7 gene encoding a novel cytokine. J BiolChem 273: 18633-18639.

49. Kustikova OS, Kiselev SL, Borodulina OR, Senin VM, Afanas'eva AV, et al. (1996) Cloning of the tag7 gene expressed in metastatic mouse tumors. Genetika 32: 621-628.

50. Vaarala O, Knip M, Paronen J, Hämäläinen AM, Muona P, et al. (1999) Cow's milk formula feeding induces primary immunization to insulin in infants at genetic risk for type 1 diabetes. Diabetes 48: 1389-1394.

51. Rother KI (2007) Diabetes treatment--bridging the divide. N Engl J Med 356: 1499-1501.

52. Abdulkarim B (2012) Effect of camel milk on blood glucose, cholesterol, triglyceride and liver enzymes activities in female Albino rats. World applied science J. 17: 1394-1397.

53. Khan AA, AlZohairy MA, Mohiedein A (2013) Antidiabetic effects of camel milk in streptozotocin-induced diabetic rats. American J. of Biochemistry and Molecular Biology 3:151-158.

54. Al-NumairKhS (2010) Type II diabetic rats and the hypolipidemic effect of camel milk. J. of food, agriculture and environment 8: 77-81.

55. El-Said EE, El-Sayed GR, Tantawy EJ (2010) Effect of camel milk on oxidative stresses in experimentally induced diabetic rabbits. Veterinary Research Forum 1:30-43.

56. Mohamad RH, Zekry ZK, Al-Mehdar HA, Salama O, El-Shaieb SE, et al. (2009) Camel milk as an adjuvant therapy for the treatment of type 1 diabetes: verification of a traditional ethnomedical practice. J Med Food 12: 461-465.

57. Agrawal RP, Beniwal R, Kochar DK, Tuteja FC, Ghorui SK, et al. (2005) Camel milk as an adjunct to insulin therapy improves long-term glycemic control and reduction in doses of insulin in patients with type- 1 diabetes A 1 year randomized controlled trial. Diabetes Res ClinPract 68: 176-177.

58. Agrawal RP, Swami SC, Beniwal R, Kochar DK, Sahani MS, et al. (2003) Effect of camel milk on glycemic control, lipid profile and diabetes quality of life in type 1 diabetes: A randomised prospective controlled cross over study. Indian J. Anim. Sci 73: 1105-1110.

59. Saitmuratova OK, Sulaimanova GI, Sadykov AA (2001) Camel's Milk and Shubat from the Aral Region. Chem. Natural Comp., 37: 566-568.

60. Matsuhisa M, Shi ZQ, Wan C, Lekas M, Rodgers CD, et al. (1997) The effect of pioglitazone on hepatic glucose uptake measured with indirect and direct methods in alloxan-induced diabetic dogs. Diabetes 46: 224-231.
61. Rerup CC (1970) Drugs producing diabetes through damage of the insulin secreting cells. Pharmacol Rev 22: 485-518.

62. Szkudelski T (2001) The mechanism of alloxan and streptozotocin action in B cells of the rat pancreas. Physiol Res 50: 537-546.

63. Tyrberg B, Andersson A, Borg LA (2001) Species differences in susceptibility of transplanted and cultured pancreatic islets to the betacell toxin alloxan. Gen Comp Endocrinol 122: 238-251.

64. Kim JM, Chung JY, Lee SY, Choi EW, Kim MK, et al. (2006) Hypoglycemic effects of vanadium on alloxan monohydrate induced diabetic dogs. J Vet Sci 7: 391-395.

65. Watanabe D, Nakara H, Yamaguchi Y, Akagi K, Hoshiya, et al. (2004) the pathological features of alloxan diabetes in beagle dogs. J. ToxicolPathol 17: 187- 195.

66. Farah Z (1996) Camel milk: Properties and products, 3rd Ed. Swiss Centre for Development. Cooperation in Technology and Management, St. Gallen, Switzerland.

67. Baumrucker CR1, Erondu NE (2000) Insulin-like growth factor (IGF) system in the bovine mammary gland and milk. J Mammary Gland BiolNeoplasia 5: 53-64.

68. Karjalainen J, Saukkonen T, Savilahti E, Dosch HM (1992) Disease associated anti-bovine serum albumin antibodies in type 1 (insulindependent) diabetes mellitus are detected by particle.concentrationfluoroimmunoassay and not by enzyme linked immunoassay. Diabetologia 35: 985-990.

69. Lévy-Marchal C, Karjalainen J, Dubois F, Karges W, Czernichow P, et al (1995) Antibodies against bovine albumin and other diabetes markers in French children. Diabetes Care 18: 1089-1094.

70. Gwinup G, Elias AN, Domurat ES (1991) Insulin and C-peptide levels following oral administration of insulin in intestinal-enzyme protected capsules. Gen Pharmacol 22: 243-246.

71. Hoffman A, Ziv E (1997) Pharmacokinetic considerations of new insulin formulations and routes of administration. ClinPharmacokinet 33: 285-301.

72. Arthur JV, Sherman JH, Luciano DS (2001) Human physiology: the mechanisms of body function. 8th Edn., McGraw-Hill, Boston; ISBN-10: 0072908017, pp: 800.

73. Lawrence RA, Lawrence RM (2010) Breastfeeding: A Guide for the Medical Professional. 7th Edn. Elsevier-Health Sciences Division, Maryland Heights ISBN: 1437707882, 1114.

74. Al-Hashem FH (2009) Camel milk alleviates oxidative stress and lipid peroxidation induced by chronic aluminum chloride exposure in rat's testes. Am. J. Applied Sci 6:1868-1875.

75. El-Fakharany EM, Tabll A, Wahahb AAE, Haroun BM, Redwan ERM (2008) Potential activity of camel milk-amylase and lactoferrin against hepatitis c virus infectivity in hepG2 and lymphocytes. Hepatitis Monthly 8: 101-109. 